\title{
Macro-channel riparian vegetation of the Olifants River System in the Grassland Biome, Mpumalanga
}

\author{
W.J. MybURGH and G.J. BREDENKAMP
}

Myburgh, W.J. and G.J. Bredenkamp. 2004. Macro-channel riparian vegetation of the Olifants River System in the Grassland Biome, Mpumalanga. Koedoe 47(1): 41-54. Pretoria. ISSN 0075-6458.

The vegetation associated with the macro-channel of the Olifants River System was investigated to identify plant communities mappable at a spatial scale of 1:250 000. The results obtained by using the PHYTOTAB PC-classification and mapping program package, revealed eight distinct plant communities associated with the macro-channel of this river system that occurs within the Grassland Biome.

Key words: macro-channel, Olifants River System, plant communities, riparian vegetation.

W.J. Myburgh $ه$, Private Bag X680, Department of Nature Conservation, Tshwane University of Technogoly, Pretoria, 0001 Republic of South Africa; G.J. Bredenkamp, Department of Botany, University of Pretoria, Pretoria, 0002 Republic of South Africa.

\section{Introduction}

The Olifants River, the second largest river in the former Transvaal (now the Limpopo Province and Mpumalanga), is one of the most severely polluted rivers in the region (Olifants River Forum 1995). This project was initiated, inter alia, to obtain a holistic perspective of the current state of the vegetation associated with the macro-channel, including the extent and distribution of exotic vegetation within the macro channel of the river system (Myburgh 2000, 2001).

In the study, which was conducted over a period of four years, the vegetation was monitored prior to and after flooding events. This report focuses on the species composition and structure of the plant communities associated with the macro-channel of the Olifants River System within the Grassland Biome.

\section{Study area}

The Grassland Biome section of the Olifants River (Fig. 1) stretches downstream from the river's origin in the vicinity of the town Breyten, to the Witbank Dam (Rutherford \& Westfall 1986). The vegetation of this area is broadly referred to as Bankenveld (Veld Type 61) (Acocks 1988).

The width of the macro-channel varies from only a few metres $(<5 \mathrm{~m})$, with no distinct riparian vegetation zone on the river banks, to $32 \mathrm{~m}$ wide with a well-developed riparian zone quite distinct from the adjacent zonal grassland. This section of the Olifants River flows through a landscape that may, in general, be described as flat to rolling plains dominated by grassland, with woody plant species restricted to the rocky river banks. The catchment area surrounding the macrochannel is mainly used for agricultural and industrial purposes, with mining activities being the most prominent.

\section{Methods}

Various researchers (Vannote et al. 1980; Ward \& Stanford 1983; Naiman et al. 1988; Townsend 1989) indicated that riparian vegetation changes downstream from the origin of a river system, as the macro-channel develops and changes. In this study, it was decided to use a spatial scale of 1:250 000, in order to include the Olifants River System from its origin to the western border of the Kruger National Park. Geological data were the most practical empirical data set available at this particular scale and were 


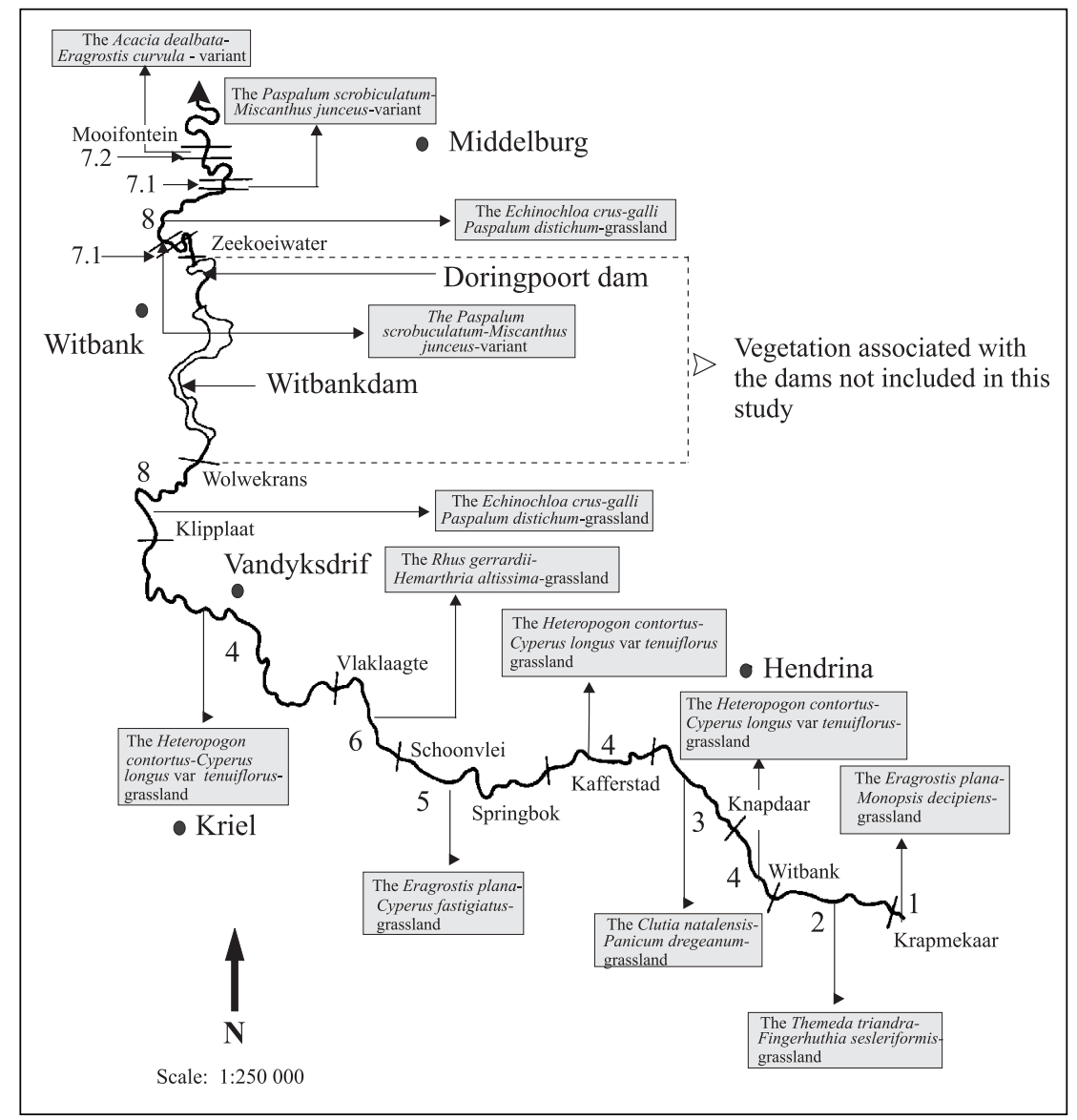

Fig. 1. Distribution of the plant communities of the Olifants River associated with the Grassland Biome.

therefore used as baseline template to stratify the landscapes through which the Olifants River flows.

The width of the riparian zone varies in correspondence to the slope and height of the banks at any given locality (Nilsson et al. 1994). An area-based vegetation sampling method was used to survey the vegetation. Variable-sized belt transects were placed within the stratified units. The number of sample plots placed in each stratified unit was calculated proportionally depending on the length of the unit. The width and length of the belt transects were influenced by the width of the channel bank and the species richness and growth forms present at a specific site. Floristic and habitat data were collected at 18 geo-referenced localities representing 36 relevés $\left(>200 \mathrm{~m}^{2}\right)$, since both macro-channel banks were surveyed as separate relevés. The floristic data recorded at each of these relevés included species composition, growth forms and canopy cover using the Plant Number Scale (Westfall \& Panagos 1988). The floristic data were analysed using the PHYTOTAB-PC computer program package (Westfall 1997).

\section{Results and discussion}

A total of eight clearly recognisable plant communities, representative of the vegetation of this section of the macro-channel of the Olifants River System (Myburgh 2000, 2001), were identified, mapped and described 
at a spatial scale of 1:250000 (Fig. 1, Table 1).

\section{The Eragrostis plana-Monopsis decipiens grassland}

The Eragrostis plana-Monopsis decipiens grassland is represented by two relevés only. This grassland community represents primarily the grassland along the macro-channel banks of that section of the Olifants River that stretches from its origin to the Nooitgedacht farm (Fig. 1). The distribution is limited to the areas associated with the Ea Land Type (Land Type Series 1985a), which are characterised by rocks from the Karoo Sequence, at an altitude of about $1750 \mathrm{~m}$ a.s.l. The soil depth at the top of the banks varies between $600 \mathrm{~mm}$ and $640 \mathrm{~mm}$.

This section of the river has a single active channel in the macro-channel floor that is 1-6 m wide (Fig. 2). The tops of the banks are flat, with a slope gradient of $\leq 1^{\circ}$, and there is no clear riparian zone. The vegetation on top of the banks may be described as typically terrestrial Eragrostis plana grassland and it cannot be visually distinguished from the surrounding grassland. There are no



Fig. 2. River profile of the Eragrostis plana-Monopsis decipiens grassland

Table 1

Mean canopy cover (M.C.C) of the plant communities identified in the Grassland Biome section of the Olifants River

\begin{tabular}{|c|c|c|c|c|c|c|}
\hline \multirow{2}{*}{$\begin{array}{l}\text { Plant } \\
\text { community } \\
\text { number }\end{array}$} & \multicolumn{5}{|c|}{ Mean canopy cover $(\%)$} & \multirow{2}{*}{$\begin{array}{l}\text { Total } \\
\text { M.C.C. } \\
(\%)\end{array}$} \\
\hline & Trees & Shrubs & $\begin{array}{l}\text { Dwarf } \\
\text { shrubs }\end{array}$ & Forbs & Grasses & \\
\hline 1 & - & - & - & 3 & 30 & 33 \\
\hline 2 & - & - & - & 10 & 32 & 42 \\
\hline 3 & - & - & 7 & 4 & 26 & 37 \\
\hline 4 & - & $<1$ & $<1$ & 5 & 50 & 56 \\
\hline 5 & - & - & 1 & 5 & 33 & 39 \\
\hline 6 & $<1$ & 4 & 2 & 9 & 23 & 38 \\
\hline 7.1 & - & 2 & $<1$ & 6 & 39 & 48 \\
\hline 7.2 & 12 & 9 & 2 & 21 & 24 & 68 \\
\hline 8 & 4 & $<1$ & $<1$ & 12 & 46 & 62 \\
\hline
\end{tabular}


Table 2

Diagnostic species of the Eragrostis plana-Monopsis decipiens - grassland (M.C.C. - mean canopy cover)

\begin{tabular}{lccc}
\hline $\begin{array}{l}\text { Species } \\
\text { name }\end{array}$ & $\begin{array}{c}\text { Growth } \\
\text { form }\end{array}$ & $\begin{array}{c}\text { Consistency } \\
(\%)\end{array}$ & $\begin{array}{c}\text { M.C.C. } \\
(\%)\end{array}$ \\
\hline $\begin{array}{l}\text { Monopsis decipiens } \\
\text { Cyperus esculentus }\end{array}$ & forb & 100 & $<1$ \\
grass & 50 & $<1$ \\
\hline
\end{tabular}

stones or rocks in the channel bed or on the banks.

This grassland is characterised by two diagnostic species (Table 2). On average, the canopy cover of both the forb Monopsis decipiens and the sedge Cyperus esculentus is $<1 \%$. Dominant grasses are Eragrostis plana, Eragrostis curvula and Cynodon dactylon. The total average canopy cover of this grassland is $33 \%$ (Table 1 ).

\section{The Themeda triandra-Fingerhuthia sesleriiformis grassland}

The Themeda triandra-Fingerhuthia sesleriiformis grassland is represented by four relevés and describes the floristics of both the macro-channel banks and the vegetation of the surrounding terrestrial grassland. As is the case with plant community 1 , this plant community (Fig. 1) is associated with the Ea
Land Type (Land Type Series 1985a) at an altitude of about $1750 \mathrm{~m}$ a.s.l., but here the rock is typically dolerite. The soil depth varies between $700 \mathrm{~mm}$ and $1000 \mathrm{~mm}$, and the soil has a high clay content throughout ( $>55 \%$ clay).

This section of the Olifants River has a single active channel that is $<17 \mathrm{~m}$ wide (Fig. 3). The river has cut into the landscape and consequently has steep macro-channel banks of about 2-3 m high. The vegetation above the macro-channel banks may be described as typical terrestrial Themeda triandra grassland on flat plains. The presence of large, isolated sheets of rock characterises parts of the active channel bed.

The grass species, Fingerhuthia sesleriiformis, Brachiaria eruciformis, Aristida bipartita, and the forb species, Hemizygia sp., Haplocarpha scaposa, Falckia oblonga, Ledebouria sp., Anthospermum pumilum subsp. rigidum, Scabiosa columbaria and Jamesbrittenia montana are diagnostic for this community (Table 3). Grass species, such as Themeda triandra and Eragrostis plana, and the forb Haplocarpha scaposa are dominant and have the highest average canopy cover. These plant species also occur in the adjacent terrestrial veld. Fingerhuthia sesleriiformis, Brachiaria eruciformis, Cirsium vulgare, Tagetes minuta and Cyperus longus var. tenuiflorus are mostly limited to

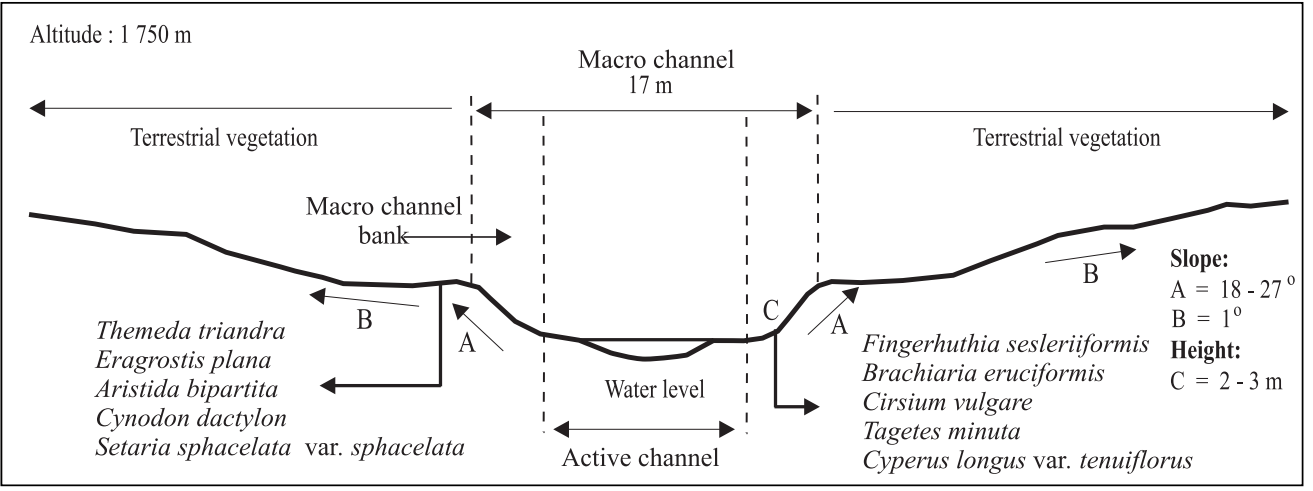

Fig. 3. River profile of the Themeda triandra-Fingerhuthia sesleriiformis grassland. 
Table 3

Diagnostic spesies of the Themeda triandra-Fingerhuthia sesleriiformis grassland (M.C.C. - mean canopy cover)

\begin{tabular}{lccc}
\hline Species name & Growth form & $\begin{array}{c}\text { Consistency } \\
(\%)\end{array}$ & $\begin{array}{c}\text { M.C.C. } \\
(\%)\end{array}$ \\
\hline Fingerhuthia sesleriiformis & grass & 100 & 3 \\
Hemizygia sp. & forb & 100 & $<1$ \\
Haplocarpha scaposa & forb & 75 & 3 \\
Falcforbia oblonga & forb & 75 & 1 \\
Ledebouria sp. & forb & 75 & $<1$ \\
Brachiaria eruciformis & grass & 75 & 1 \\
Anthospermum pumilum subsp. rigidum & forb & 50 & $<1$ \\
Scabiosa columbaria & forb & 50 & $>1$ \\
Jamesbrittenia montana & forb & 50 & $<1$ \\
Aristida bipartita & grass & 50 & 2 \\
\hline
\end{tabular}

the macro-channel banks and active channel bed. A woody component is absent in this grassland community. The total average canopy cover of the Themeda triandra-Fingerhuthia sesleriiformis grassland is $42 \%$ (Table 1).

\section{The Clutia natalensis-Panicum dregeanum grassland}

The Clutia natalensis-Panicum dregeanum grassland is represented by two relevés and occurs on both the macro-channel banks and the terrestrial area above the banks. This plant community is situated in the vicinity of the Frischgewaagd farm (Fig. 1). It is a grassland community found where the Olifants River runs through the Bb Land Type (Land Type Series 1985a), associated with the Karoo Sequence and aeolic sand at an altitude of about $1650 \mathrm{~m}$ a.s.l. The deep $(\geq 1200 \mathrm{~mm}$ ) soil on the macro-channel banks is typically a sand-deposit covering clayey subsoil ( $>55 \%$ clay).



Fig. 4. River profile of the Clutia natalensis-Panicum dregeanum grassland. 
Table 4

Diagnostic species of the

Clutia natalensis-Panicum dregeanum grassland (M.C.C. - mean canopy cover)

\begin{tabular}{lccc}
\hline Species name & $\begin{array}{c}\text { Growth } \\
\text { form }\end{array}$ & $\begin{array}{c}\text { Consistency } \\
(\%)\end{array}$ & $\begin{array}{c}\text { M.C.C. } \\
(\%)\end{array}$ \\
\hline Panicum dregeanum & grass & 100 & 2 \\
Artemisia afra & $\begin{array}{l}\text { dwarf } \\
\text { shrub }\end{array}$ & 100 & 7 \\
$\begin{array}{l}\text { Oenothera } \\
\text { erythrosepala }\end{array}$ & forb & 100 & $<1$ \\
\hline
\end{tabular}

The macro-channel in this section of the river is, on average, $14 \mathrm{~m}$ wide and the steep macro-channel banks are similar to the Themeda triandra-Fingerhuthia sesleriiformis grassland (Fig. 4). The surrounding grassland above the banks is situated on flat to convex plains, with a clear riparian zone limited to the macro-channel banks. This grassland community is characterised by the presence of a woody component, with the dwarf shrub species Clutia natalensis, Artemisia afra and Gomphocarpus fruticosus limited to the steep macro-channel banks, while the reed Phragmites australis and forb Persicaria lapathifolia are found at the waterside in the active channel.
The grass Panicum dregeanum, forb Oenothera erythrosepala, and dwarf shrub Artemisia afra are diagnostic for this community (Table 4). Dominant dwarf shrub species are Clutia natalensis and Artemisia afra, while Themeda triandra, Eragrostis curvula, Setaria sphacelata var. sphacelata, Andropogon appendiculatus and Hyparrhenia tamba mostly dominate the grass layer. The total average canopy cover of this grassland is $37 \%$ (Table 1).

\section{The Heteropogon contortus-Cyperus longus var. tenuiflorus grassland}

The Heteropogon contortus-Cyperus longus var. tenuiflorus grassland is represented by seven relevés and occurs on both the steep macro-channel banks and the terrestrial area above the banks. This plant community (Fig. 1) is associated with that section of the Olifants River that is situated in the $\mathrm{Bb}$ Land Type (Land Type Series 1985a) with sandstones and shales from the Karoo Sequence. Deep soil (1 000-1 $200 \mathrm{~mm})$ is common and the soil texture varies from sandy loam (11\% to $15 \%$ clay) to clayey soil ( $>55 \%$ clay).

The width of the macro-channel varies from 15-27 m (Fig. 5). The river has cut deeply into the landscape, and steep macro-channel

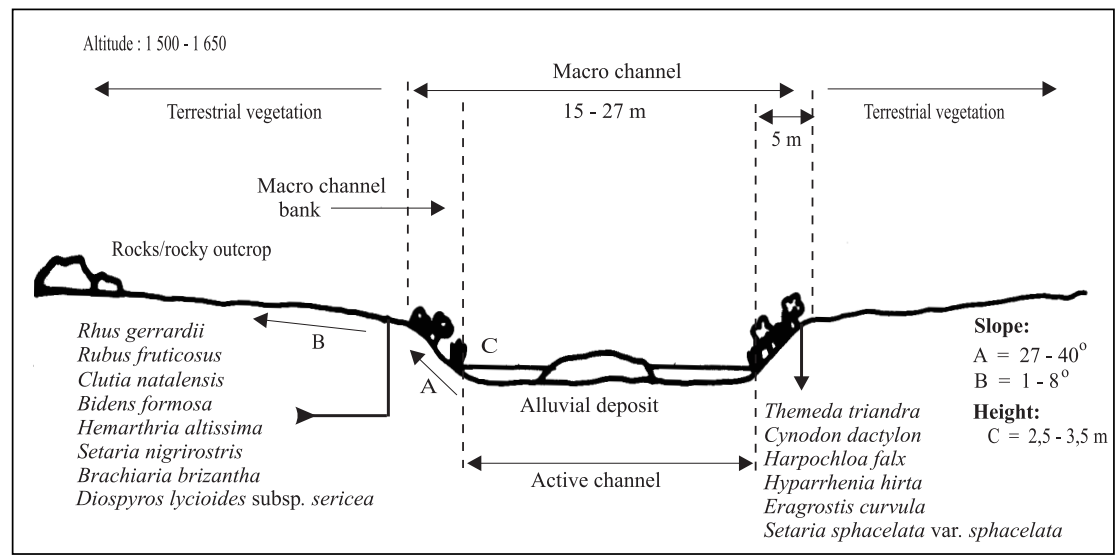

Fig. 5. River profile of the Heteropogon contortus-Cyperus longus var. tenuiflorus grassland. 
Table 5

Diagnostic species of the Heteropogon contortusCyperus longus var. tenuiflorus grassland

(M.C.C. - mean canopy cover)

\begin{tabular}{llcc}
\hline Species name & $\begin{array}{c}\text { Growth } \\
\text { form }\end{array}$ & $\begin{array}{c}\text { Constancy } \\
(\%)\end{array}$ & $\begin{array}{c}\text { M.C.C. } \\
(\%)\end{array}$ \\
\hline Heteropogon contortus & grass & 71 & 2 \\
Eragrostis gummiflua & grass & 71 & $<1$ \\
Elionurus muticus & grass & 43 & $<1$ \\
Bidens formosa & forb & 43 & $<1$ \\
Alloteropsis semialata & grass & 29 & $<1$ \\
$\begin{array}{ll}\text { Acalypha caperonioides } \\
\text { Aristida congesta }\end{array}$ & forb & 29 & $<1$ \\
$\begin{array}{l}\text { subsp. congesta } \\
\text { Aristida } \text { sp. }\end{array}$ & grass & 29 & $<1$ \\
$\begin{array}{l}\text { Pteridium aquilinum } \\
\text { grass }\end{array}$ & forb & 29 & 3 \\
\hline
\end{tabular}

banks, up to $3.5 \mathrm{~m}$ high, are common. The landscape above the banks is flat to convex and has slopes with gradients of $1-8^{\circ}$. Riparian vegetation is limited to the macrochannel banks. Woody vegetation is mostly limited to rocky areas along the macro-channel banks.

The active channel bed has alluvial deposits or sand banks (depositional bars), and large rocks are quite common on both the macrochannel banks and in the active channel. This section of the active channel is characterised by pools, and a few rapids. In certain areas mining activities have seriously disturbed the adjacent terrestrial vegetation, while planted pastures that stretch down to the macro-channel replaced the natural grassland.

Diagnostic species are, inter alia, the grasses Heteropogon contortus, Eragrostis gummiflua, Elionurus muticus, Alloteropsis semialata, Aristida congesta subsp. congesta, Aristida sp., the forbs Bidens formosa, Acalypha caperonoides, and the fern Pteridium aquilinum (Table 5). The grass layer is completely dominated by Themeda triandra, followed by Cynodon dactylon, Aristida sp., patches of Phragmites australis and Hyparrhenia tamba. Dominant sedges are Cyperus longus var. tenuiflorus and Cyperus lati- folius. These species, and Phragmites australis, are, however, limited to the waterside and alluvial deposits (depositional bars) in the active channel. The grasses Brachiaria brizantha, Hemarthria altissima and the forb Persicaria lapathifolia are also associated with the lower-lying, moister sections of the macro-channel banks.

The shrub component is represented by Rubus fruticosus, Rhus gerrardii and Diospyros lycioides subsp. sericea. The latter shrub is associated with stony and rocky substrates, similar to the surrounding terrestrial Bankenveld substrates. The average canopy cover of these three species is less than $1 \%$, while the total average canopy cover of the Heteropogon contortus-Cyperus longus var. tenuiflorus grassland is $56 \%$ (Table 1).

\section{The Eragrostis plana-Cyperus fastigia- tus grassland}

The Eragrostis plana-Cyperus fastigiatus grassland is represented by five relevés and occurs both on the macro-channel banks and the terrestrial area above the banks. This plant community is associated with the Olifants River in the vicinity of the Middelkraal farm and it also occurs in the vicinity of the Vandyksdrift farm (Fig. 1). This grassland is associated with the $\mathrm{Bb}$ and $\mathrm{Fa}$ Land Types (Land Type Series 1985a) at an altitude of about $1600 \mathrm{~m}$ a.s.l. Typical underlying rocks are, inter alia, sandstone, shale, layered mudstone and rhyolite from the Karoo and Transvaal Sequences. The soil depth varies (1 000-1 $200 \mathrm{~mm}$ ), and the soil texture ranges from sandy clay loam to loamy clays throughout this community. Soil texture varies from $21 \%$ to $55 \%$ clay.

The macro-channel of this section of the Olifants River is, on average, $16 \mathrm{~m}$ wide with a single active channel (Fig. 6). The river typically has steep macro-channel banks. Above ground rock occurs only in a few isolated areas, either on the banks or in the active channel. Locally, alluvial deposits or sand banks (depositional bars) are found in the active channel. 


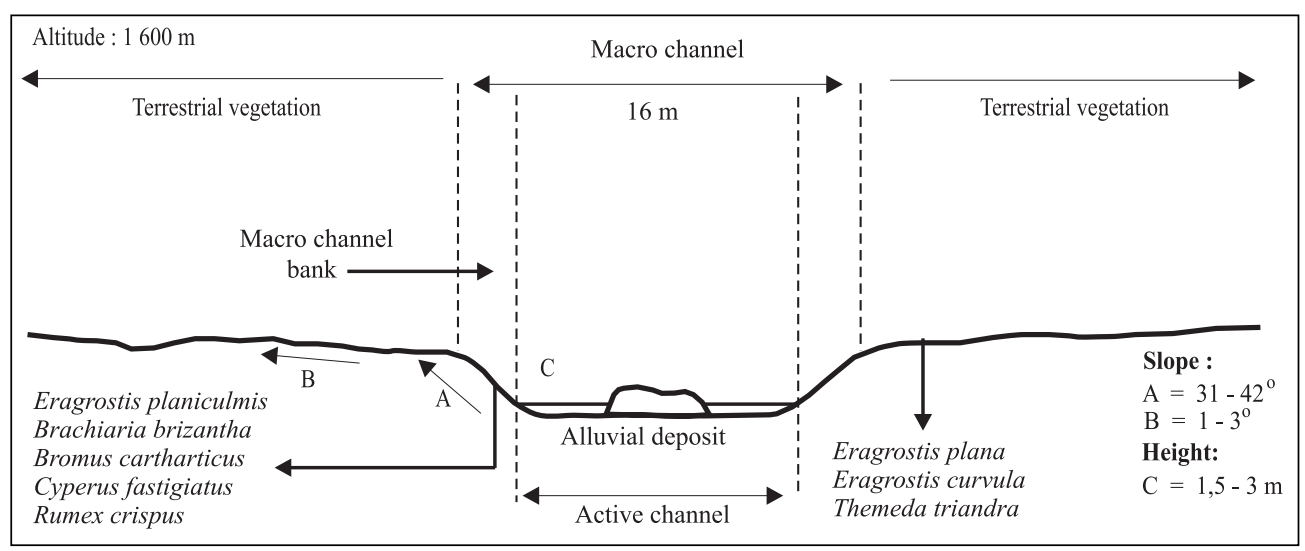

Fig. 6. River profile of the Eragrostis plana-Cyperus fastigiatus grassland.

The grass Bromus catharticus and forbs Cirsium vulgare and Crabbea acaulis are diagnostic for this grassland community (Table 6). The grasses Eragrostis planiculmis, Brachiaria brizantha, Bromus cartharticus, the sedge Cyperus fastigiatus and the forbs Rumex crispus and Persicaria lapathifolia are dominant on the steep macro-channel banks and at the waterside. The grass Eragrostis plana and to a lesser degree Eragrostis curvula and Themeda triandra are dominant above the banks.

Only three dwarf shrub species are found in this community and Clutia natalensis has the highest average canopy cover. The dwarf shrubs Gomphostigma virgatum and Gomphocarpus physocarpus were recorded only in one relevé and are poorly represented. The

Table 6

Diagnostic species of the Eragrostis plana-Cyperus fastigiatus grassland (M.C.C. - mean canopy cover)

\begin{tabular}{lccc}
\hline Species name & $\begin{array}{c}\text { Growth } \\
\text { form }\end{array}$ & $\begin{array}{c}\text { Constancy } \\
(\%)\end{array}$ & $\begin{array}{c}\text { M.C.C. } \\
(\%)\end{array}$ \\
\hline Bromus catharticus & grass & 40 & $<1$ \\
Cirsium vulgare & forb & 60 & $<1$ \\
Crabbea acaulis & forb & 40 & $<1$ \\
\hline
\end{tabular}

average total canopy cover of the Eragrostis plana-Cyperus fastigiatus grassland is $39 \%$ (Table 1).

\section{The Rhus gerrardii-Hemarthria altissima grassland}

The Rhus gerrardii-Hemarthria altissima grassland is, as is the case with the Eragrostis plana-Cyperus fastigiatus grassland (community 5), associated with the $\mathrm{Bb}$ and Fa Land Types (Land Type Series 1985a), but it occurs at an altitude of about $1550 \mathrm{~m}$ a.s.1. (Fig. 1). The Karoo and Transvaal Sequences represent the geology of this area. Soil depth varies from $600 \mathrm{~mm}$ to $1200 \mathrm{~mm}$ with a clay content of higher than $55 \%$. This vegetation is represented by six relevés.

The macro-channel has a single active channel varying between $19 \mathrm{~m}$ and $22 \mathrm{~m}$ in width, with pools and rapids succeeding each other (Fig. 7). The river flows through rocky ridges, consequently the above-ground rock cover is high in both the active channel bed and on the macro-channel banks. Stone sizes vary from large stones ( $>250 \mathrm{~mm}$ ) to boulders $(>1000 \mathrm{~mm})$. It may be assumed that this high rock cover would play a stabilising role on both the macro-channel banks and in the active channel bed, and that it would 


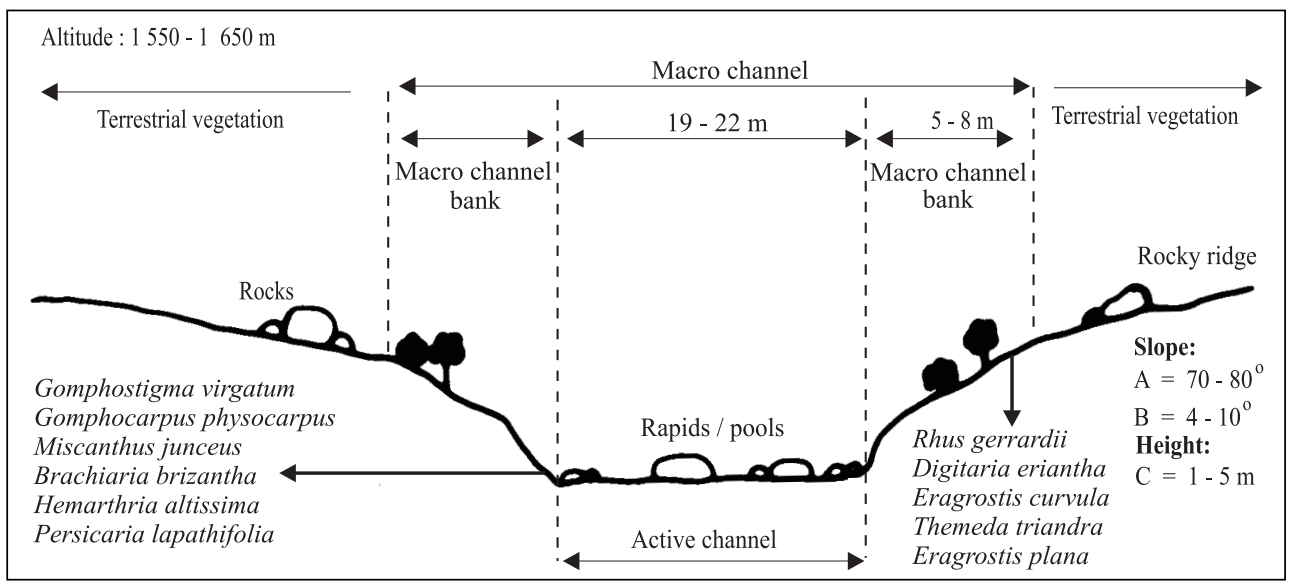

Fig. 7. River profile of the Rhus gerrardii-Hemarthria altissima grassland.

influence the water flow pattern, and consequently, that this section of the river would not be influenced as much as other sections by floods. The riparian zone is characterised by the presence of a shrub component.

The exotic, though naturalised, tree Salix babylonica and forbs Galium capense subsp. garipense, Argyrolobium tuberosum, Helichrysum mundtii and Polygala hottentotta are diagnostic for this grassland community (Table 7). The dwarf shrubs, Gom-

Table 7

Diagnostic species of the Rhus gerrardiiHemarthria altissima grassland (M.C.C. - mean canopy cover)

\begin{tabular}{lccc}
\hline Species name & $\begin{array}{c}\text { Growth } \\
\text { form }\end{array}$ & $\begin{array}{c}\text { Constancy } \\
(\%)\end{array}$ & $\begin{array}{c}\text { M.C.C. } \\
(\%)\end{array}$ \\
\hline $\begin{array}{l}\text { Galium capense } \\
\text { subsp. garipense }\end{array}$ & forb & 50 & 2 \\
$\begin{array}{l}\text { Argyrolobium } \\
\text { tuberosum }\end{array}$ & forb & 67 & $<1$ \\
$\begin{array}{l}\text { Helichrysum } \\
\text { mundtii }\end{array}$ & forb & 33 & $<1$ \\
$\begin{array}{l}\text { Polygala } \\
\text { hottentotta }\end{array}$ & forb & 33 & $<1$ \\
$\begin{array}{l}\text { Salix babylonica } \\
\text { tree }\end{array}$ & 33 & $<1$ \\
\hline
\end{tabular}

phostigma virgatum and Gomphocarpus physocarpus, the grasses, Miscanthus junceus, Brachiaria brizantha and Hemarthria altissima and the forb Persicaria lapathifolia are dominant at the waterside and in the lower-lying parts of the macro-channel bank.

Rhus gerrardii is the only shrub recorded. It has an average canopy cover of $3.91 \%$. The tree Salix babylonica was recorded at only two sites. It has an average canopy cover of $<1 \%$. Digitaria eriantha, Brachiaria brizantha, Eragrostis curvula, Hemarthria altissima, Miscanthus junceus, Themeda triandra and Eragrostis plana are dominant in the grass stratum while the forb species Galium capense subsp. garipense, Persicaria lapathifolia and Tagetes minuta are commonly found. The average total canopy cover of the Rhus gerrardii-Hemarthria altissima grassland is $38 \%$ (Table 1).

7. The Salix mucronata subsp. wilmsiiEragrostis curvula grassland

The Salix mucronata subsp. wilmsii-Eragrostis curvula grassland is represented by six relevés. This plant community is associated with the $\mathrm{Bb}$ Land Type (Land Type Series 1985b) at altitudes ranging between 


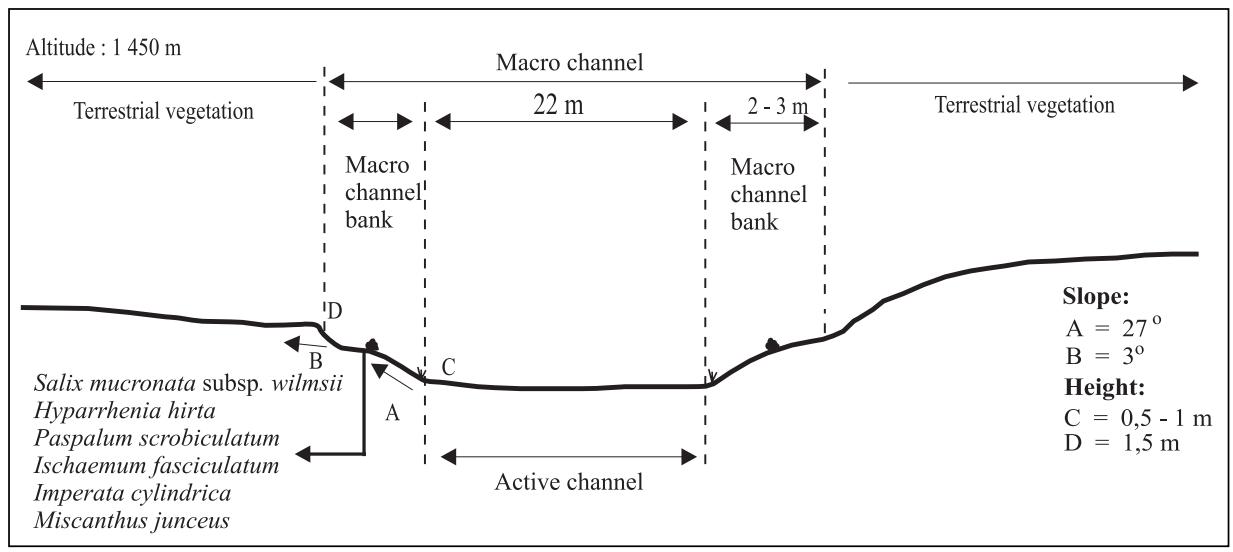

Fig. 8. River profile of the Paspalum scrobiculatum-Miscanthus junceus variant.

$1425 \mathrm{~m}$ and $1450 \mathrm{~m}$ a.s.l. This grassland is limited to narrow, easily distinguishable diabase dykes and intrusions crossing the Olifants River, immediately north of the Doringpoort Dam, in the vicinity of the town Witbank (Fig. 1).

The shrub Salix mucronata subsp. wilmsii and the grass Ischaemum fasciculatum are diagnostic for this community. The commu-

Table 8

Diagnostic species of the Paspalum scrobiculatumMiscanthus junceus variant

(M.C.C. - mean canopy cover)

\begin{tabular}{lccc}
\hline Species name & $\begin{array}{c}\text { Growth } \\
\text { form }\end{array}$ & $\begin{array}{c}\text { Constancy } \\
(\%)\end{array}$ & $\begin{array}{c}\text { M.C.C. } \\
(\%)\end{array}$ \\
\hline $\begin{array}{l}\text { Paspalum } \\
\text { scrobiculatum }\end{array}$ & grass & 100 & 2 \\
$\begin{array}{l}\text { Chamaecrista } \\
\text { comosa }\end{array}$ & forb & 100 & $<1$ \\
$\begin{array}{l}\text { Imperata } \\
\text { cylindrica }\end{array}$ & grass & 50 & 7 \\
$\begin{array}{l}\text { Plantago virginica } \\
\text { Ipomoea crassipes }\end{array}$ & forb & 50 & $<1$ \\
$\begin{array}{l}\text { Cynoglossum } \\
\text { lanceolatum }\end{array}$ & forb & 50 & $<1$ \\
\hline
\end{tabular}

nity is divided into two variants, namely the Paspalum scrobiculatum-Miscanthus junceus variant (variant 7.1) and the Acacia dealbata-Eragrostis curvula variant (variant 7.2). The most significant difference in the habitats of these two variants lies in soil depth and above ground rock cover. The Paspalum scrobiculatum-Miscanthus junceus variant is found on deep soil with a low rock cover, while the Acacia dealbata-Eragrostis curvula variant is found on shallow soil with a high rock cover.

There is also a great difference in the vegetation structure of these two variants. The woody component of variant 7.1 is limited to a few dwarf shrub and shrub species with a low average canopy cover, in comparison with the woody component of variant 7.2, which consists of tree, shrub and dwarf shrub species. The tree Acacia dealbata (a declared alien invader,) and shrub Sesbania punicea (a declared weed), dominate the macro-channel banks of variant 7.2 and contribute largely to the total canopy cover of the woody component of this variant. However, these two alien problem species are not found in the Paspalum scrobiculatum-Miscanthus junceus variant. There is also a huge difference in the floristic composition between 
these variants that are limited to the diabase intrusions.

\subsection{Paspalum scrobiculatum-Miscanthus junceus variant}

The Paspalum scrobiculatum-Miscanthus junceus variant is represented by two relevés only, and the extent of this unit is limited. The macro-channel is up to $22 \mathrm{~m}$ wide and deep, stagnant pools of water are predominant (Fig. 8). The macro-channel banks form flat to convex terraces and the above ground rock cover is limited to a few pebbles in the active channel bed. The sandy clay loam soil is deep ( $\geq 1200 \mathrm{~mm}$ ) and has a clay content of $21 \%$ to $35 \%$.

This variant has six diagnostic species (Table 8), and the grass Paspalum scrobiculatum and forb Chamaecrista comosa, have been recorded only on the macro-channel banks.

The shrub layer of this variant is dominated by Salix mucronata subsp. wilmsii. The shrubs Diospyros lycioides subsp. sericea and Rhus gerrardii are poorly represented in this variant. Hyparrhenia hirta, Paspalum scrobiculatum, Ischaemum fasciculatum, Imperata cylindrica, Setaria sphacelata var. sphacelata, Hemarthria altissima and Mis- canthus junceus dominate the grass layer. The grass species Miscanthus junceus together with the sedge species, Cyperus latifolius, Cyperus marginatus, Cyperus longus var. tenuiflorus are limited to the lower-lying terraces on the macro-channel banks and the areas bordering the active channel.

The variant represents the vegetation associated with the macro-channel bank as well as the vegetation above the macro-channel bank. There is no single dominant forb species. All the forb species present have an average canopy cover of less than $1 \%$. However, the joint, average canopy cover of the forbs is $6 \%$. Forb species that make the largest contribution are Crabbea acaulis, Berkheya radula, Ipomoea bathycolpos, Ipomoea crassipes, Helichrysum rugulosum and Tagetes minuta. The total average canopy cover of the Paspalum scrobiculatum-Miscanthus junceus variant is $48 \%$ (Table 1 ).

\subsection{Acacia dealbata-Eragrostis curvula variant}

The Acacia dealbata-Eragrostis curvula variant is represented by four relevés. The macro-channel divides in certain areas to form two active channels that are between $23 \mathrm{~m}$ and $25 \mathrm{~m}$ wide (Fig. 9). These active channels are characterised by shallow pools

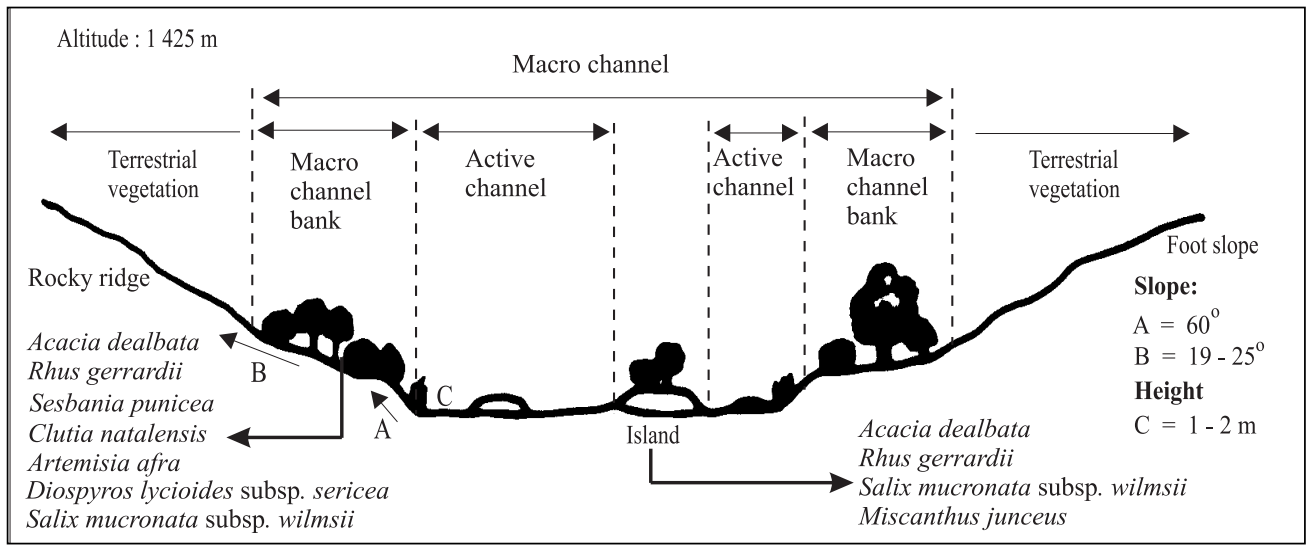

Fig. 9. River profile of the Acacia dealbata-Eragrostis curvula variant. 
Table 9

Diagnostic species of the Acacia dealbata-Eragrostis curvula variant (M.C.C. - mean canopy cover)

\begin{tabular}{lccc}
\hline Species name & $\begin{array}{c}\text { Growth } \\
\text { form }\end{array}$ & $\begin{array}{c}\text { Constancy } \\
(\%)\end{array}$ & $\begin{array}{c}\text { M.C.C. } \\
(\%)\end{array}$ \\
\hline Acacia dealbata & tree & 75 & 12 \\
Sesbania punicea & shrub & 100 & 2 \\
Deverra sp. & forb & 75 & $<1$ \\
Acacia karroo & dwarf shrub & 75 & $<1$ \\
Bidens pilosa & forb & 50 & 2 \\
Dicliptera clinopodia & forb & 75 & 1 \\
Lepidium virginicum & forb & 75 & $<1$ \\
Ranunculus multifidus & forb & 50 & $<1$ \\
Sida rhombifolia & dwarf shrub & 50 & $<1$ \\
Vangueria cyanescens & shrub & 50 & $<1$ \\
Maytenus heterophylla & shrub & 50 & $<1$ \\
Chenopodium ambrosioides & forb & 50 & $<1$ \\
Typha capensis & grass & 50 & $<1$ \\
Achyranthes aspera var. aspera & forb & 50 & $<1$ \\
\hline
\end{tabular}

shrubs Clutia natalensis and Artemisia afra. The grasses Eragrostis plana, Miscanthus junceus, Hemarthria altissima, Eragrostis curvula and Paspalum distichum, and the sedges Cyperus marginatus and Cyperus latifolius dominate the grass layer. The grass species Miscanthus junceus, Hemarthria altissima, Paspalum distichum, Phragmites australis, and sedge species Cyperus marginatus and Cyperus latifolius are mostly limited to the lower-lying parts of the macro-channel bank close to the active channels.

The macro-channel banks are disturbed in local areas. The high average canopy cover of the opportunistic weedy forbs Tagetes minuta, Verbena bonariensis and

followed by rapids, and by the presence of a few islands on which woody plant species are found. The riparian zone is clearly visible with a strong woody component.

The soil on the macro-channel banks is $150 \mathrm{~mm}$ to $200 \mathrm{~mm}$ deep and the soil texture varies from loamy sand (11\% $-15 \%$ clay) to clayey soil ( $>55 \%$ clay). This section of the river is characterised by a high percentage rock cover. The stones vary from pebbles limited to the active channel bed to large stones and rocks that occur mostly on the macro-channel banks.

This variant has 14 diagnostic species (Table 9). The declared alien invader Acacia dealbata and the declared alien weed Sesbania punicea have the highest average canopy cover. These species should be removed, since they both grow near the waterside and are a source of seed that may spread to downstream areas.

The Acacia dealbata-Eragrostis curvula variant is characterised by the presence of a strong woody component. Dominant woody species are the tree Acacia dealbata, the shrubs Sesbania punicea, Diospyros lycioides subsp. sericea, Salix mucronata subsp. wilmsii, Rhus gerrardii, and the dwarf
Bidens pilosa confirms that disturbance. The high weed cover probably results from the high woody cover and its shadow effect - the alien tree Acacia dealbata, with an average canopy cover of $12 \%$, being the greatest contributor. The negative shadow effect is clearly visible on the grass layer. The total average canopy cover of the Acacia dealbata-Eragrostis curvula variant is $68 \%$ (Table 1).

\section{The Echinochloa crus-galli-Paspalum distichum grassland}

The Echinochloa crus-galli-Paspalum distichum grassland is represented by four relevés and it occurs south of Witbank Dam in the vicinity of the Wolwekrans farm and downstream of the Doringpoort Dam (Fig. 1). The plant community is associated with the Bb Land Type (Land Type Series $1985 \mathrm{~b}$ ) and is found at altitudes of $1450 \mathrm{~m}$ to $1500 \mathrm{~m}$ a.s.l. The typical underlying geology is derived from the Loskop Formation and the Karoo Sequence, Group Ecca, and mostly consists of sandstone, shale and conglomerate. The soil is mostly $1200 \mathrm{~mm}$ deep and varies from sandy clay loam $(21 \%$ $35 \%$ clay) to heavy clayey soil ( $>55 \%$ clay). 


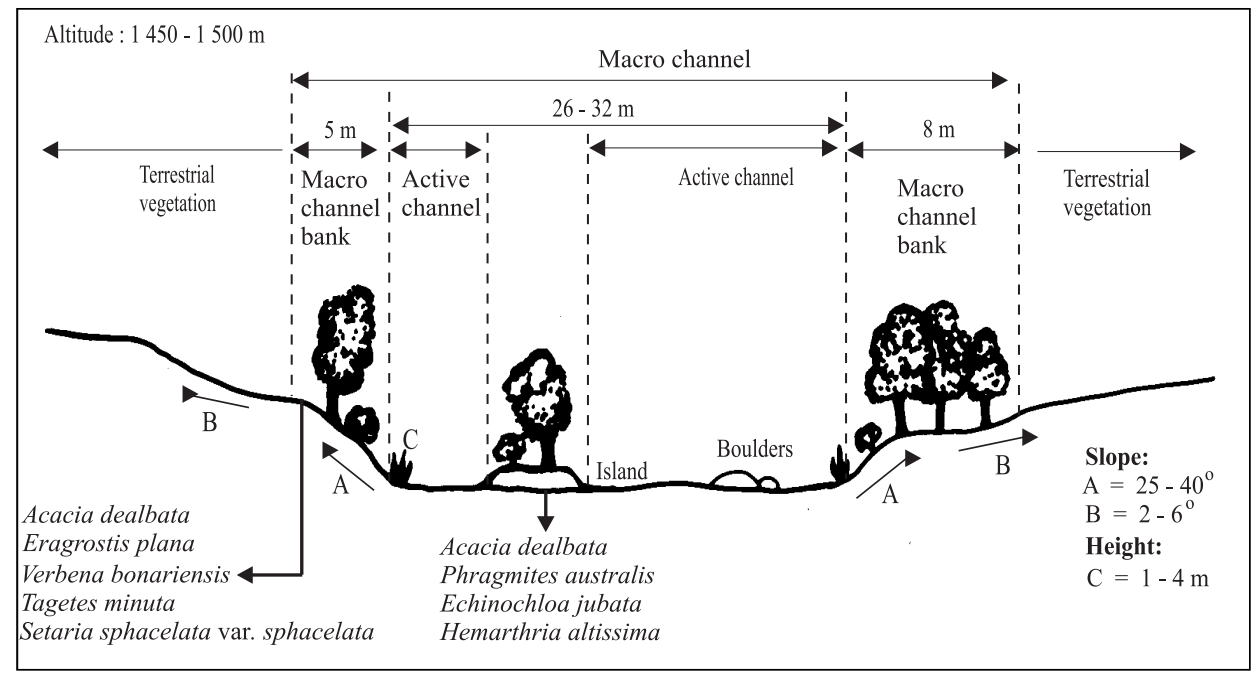

Fig. 10. River profile of the Echinochloa crus-galli-Paspalum distichum grassland.

The width of the macro-channel varies between $26 \mathrm{~m}$ and $32 \mathrm{~m}$ with steep banks up to $4 \mathrm{~m}$ high (Fig. 10). A single active channel has a rocky appearance in certain areas, and divides to form two active channels with an island covered by a dwarf shrub component.

The grasses Echinochloa crus-galli and Echinochloa jubata, the sedge Juncus effusus, the forb Cotula anthemoides and the alien tree Morus alba are diagnostic for this grassland community (Table 10). The tree

Table 10

Diagnostic species of the Echinochloa crus-galli-

Paspalum distichum grassland

(M.C.C. - mean canopy cover)

\begin{tabular}{lccc}
\hline Species name & $\begin{array}{c}\text { Growth } \\
\text { form }\end{array}$ & $\begin{array}{c}\text { Constancy } \\
(\%)\end{array}$ & $\begin{array}{c}\text { M.C.C. } \\
(\%)\end{array}$ \\
\hline Echinochloa crus-galli & grass & 75 & $<1$ \\
Echinochloa jubata & grass & 50 & 10 \\
Juncus effusus & grass & 50 & $<1$ \\
Morus alba & tree & 50 & $<1$ \\
Cotula anthemoides & forb & 50 & $<1$ \\
\hline
\end{tabular}

component of this community is represented by Acacia dealbata, Morus alba and Rhus lancea. However, the latter two species have low average canopy covers. The woody species have a low constancy throughout.

The grasses Eragrostis plana, Phragmites australis, Setaria sphacelata var. sphacelata, Echinochloa jubata, Cyperus latifolius and Paspalum distichum and the sedge Cyperus fastigiatus dominate the grass layer, while Verbena bonariensis, Persicaria lapathifolia and Tagetes minuta dominate the forb layer. The sedges Cyperus latifolius and Cyperus fastigiatus, the reed, Phragmites australis, the grasses Echinochloa jubata, Paspalum distichum and Hemarthria altissima and the forb Persicaria lapathifolia are mostly limited to the watersides of the macro-channels. Phragmites australis is also associated with the active channel bed and islands.

The total average canopy cover of the Echinochloa crus-galli-Paspalum distichum grassland is $62 \%$, with grass species making the largest contribution (Table 1). 


\section{Discussion and conclusion}

The spatial scale of 1:250 000 at which the stratification and sampling took place, caused the vegetation on the macro-channel banks and the vegetation on top of the banks to be seen and described as a single unit. The species composition, representing both macro channel and terrestrial vegetation, therefore, may seem strange, unless it is taken into account that specific plant species are associated with the lower-lying sections bordering the waterside and that other plant species are associated with the banks or even on top of the banks. The locality and distribution of the species were however recorded and described.

The riparian vegetation of the macro-channel in the Grassland Biome is not clearly distinguishable from the surrounding vegetation and is mainly represented by terrestrial grass species. A few indigenous woody species occur in the rocky areas associated with the macro-channel. Floristic differences occur within and between communities due to changes in habitat but also as a result of different land use practices and intensities of utilisation. In certain areas the river was diverted due to mining activities and the natural vegetation replaced with planted pastures. The alteration of riverbanks and the occurrence of exotic woody species in certain areas modify the stabilising role of the indigenous vegetation and influence hydrological processes. Acacia dealbata and the declared alien weed Sesbania punicea pose a threat to the biodiversity of the macro-channel and should be removed. These species grow near the waterside and are a source of seed, spreading to the downstream areas. Although time consuming and costly, it is important to obtain geo-referenced baseline data for these longitudinally narrow ecosystems, in order to manage and monitor vegetation change over time.

\section{Acknowledgements}

This project was made possible by funds donated by the Water Research Commission and the use of the facilities at the Agricultural Research Council.

\section{References}

ACOCKS, J.P.H. 1988. Veld types of Southern Africa. (3rd. ed) Memoirs of the botanical Survey of South Africa 57:1-146.

Land Type Series. 1985a. Land Type Map 2628 East Rand (1:250 000). Pretoria: Government Printer.

Land Type Series. 1985b. Land Type Map 2528 Pretoria (1:250 000). Pretoria: Government Printer.

MyburGh, W.J. 2000. Oewerplantegroei van die Olifantsriviersisteem-'n Ekologiese perspektief. Water Research Commission. ISBN No 1868455688.

Myburgh, W.J. 2001. Die ekologie en plantegroeibestuur van die Olifantsriviersisteem. $\mathrm{PhD}$ thesis, University of Pretoria, Pretoria.

Naiman, R.J., H. Decamps, J. Pastor \& A.C. JohnSTON. 1988. The potential importance of boundaries to fluvial ecosystems. Journal of the North American Benthological Society 7:289-306.

Nillson, C., A. Ekblad, M. Dynesius, S. Backe, M. Gardfjell, B. Carlberg, S. Hellqvist \& R. JANSSON. 1994. A comparison of species richness and traits of riparian plants between a main river channel and its tributaries. Journal of Ecology 82:281-295.

Olifants River Forum. 1995. Save water-or face wars. On track (October/November): 60-61.

Rutherford, M.C. \& R.H. WestFall. 1986. Biomes of Southern Africa-an objective categorization. Memoirs of the botanical Survey of South Africa 54: 45-65.

TownSEND, C.R. 1989. The patch dynamics concept of stream community ecology. Journal of the North American Benthological Society 8:36-50.

Vannote, R.L., G.W. Minshall, K.W. Cummins, J.R. Sedell \& C.E. Cushing. 1980. The river continuum concept. Canadian Journal of Fisheries and Aquatic Science 37:130-137.

WARD, J.V. \& J.A. STANFORD. 1987. The ecology of regulated streams: past accomplishments and directions for future research. Pp. 391-409. In: Craig, J.F. \& J.B. Kemper (eds.). Regulated Streams. Advances in Ecology. New York: Plenum Press.

Westfall, R.H. \& M.D. Panagos. 1988. The Plant Number Scale - an improved method for cover estimation using variable belt transects. Bothalia 18(2): 289-291.

Westfall, R.H., G.K. Theron \& N. Van Rooyen. 1997. Objective classification and analysis of vegetation data. Plant Ecology 132: 137-154. 